\title{
Classroom Guidance Strategy with Flipped Method in Guidance and Counseling Services at Indonesia Schools in the Digital Era
}

\author{
Mulawarman Mulawarman ${ }^{1 *}$, Susilawati Susilawati ${ }^{2}$, \\ Layyinatus Syifa ${ }^{1}$, Endang Rifani ${ }^{3}$ \\ Universitas Negeri Semarang, Indonesia ${ }^{1}$ \\ Universitas Bengkulu, Indonesia ${ }^{2}$ \\ Universitas PGRI Semarang, Indonesia ${ }^{3}$ \\ @mulawarman@mail.unnes.ac.id ${ }^{*}$
}

\section{Article Information:}

Received December 3, 2019

Revised January 21, 2020

Accepted January 29, 2020

Keywords: classroom guidance; flipped classroom; guidance and counseling

\section{Abstract}

The demand for a better education system will result in not only a better academic achievement but also students with better character. Particularly in this digital era, it is very important to integrate technology in the process of guidance and counseling services at schools. This article aims to provide a critical review of implementation and application of classical guidance with format flipped classroom in coping with the advance of technology as an effort that can be made by school counselors in order to make innovation in guidance and counseling service at schools. This research method is a literature study. This study collected and analyzed relevant journals related to the use of flipped classroom. Class guidance with flipped classroom format has the potential to help school counselors to manage classical guidance and stimulate students to be active, communicative, and contributive to the process of guidance so that the topic presented can be addressed directly. In addition, by doing this, it is expected that students can develop themselves well in their social, academic, and career life. School counselors can use flipped classroom guidance to make innovation in performing classroom guidance services. The steps to perform flipped classroom guidance, in brief, are determine the topic to be discussed based on the need of the student, creating service program plan, then setting up the activities that the students will do in pre-class activity and inside the class, the implementation of the activities and evaluation, and follow up.

\section{INTRODUCTION}

Guidance and counseling service at schools has four service components covering basic service, responsive service, individual planning service, and system support (Depdiknas, 2007). These four components are following what has been developed by the American School Counselor Association (ASCA, 2012) in the framework model of school counselors in America. One of the counseling and guidance service components that are often used in the school setting is basic service. Basic service in guidance and counseling are provided to the student through group and classical guidance to assist students in achieving developmental assignments. Basic service is the first step for school counselors to be able to identify the need of students. Classroom guidance as one of the services which are used to identify the need of

How to cite:

E-ISSN:

Published by:
Mulawarman, M., Susilawati, S., Syifa, L., \& Rifani, E. (2020). Classroom Guidance Strategy with Flipped Method in Guidance and Counseling Services at Indonesia Schools in the Digital Era. Islamic Guidance and Counseling Journal, 3(2). https://doi.org/10.25217/igcj.v3i2.646 2614-1566

Institut Agama Islam Ma'arif NU (IAIMNU) Metro Lampung 
the students should be made as interesting as it can be. Not only does the material need to be considered, but also the way the material is addressed needs to be efficient.

The real condition shows that the implementation of classroom guidance service particularly in Indonesia has not run at its best. There are still many problems found in the implementation either the problem related to the allocation of time or the problem regarding the use of technology by school counselors. Rismawati (2015) found that tend to feel difficult to concentrate when school counselors give information in the classroom. This was because classical to guidance service was conducted at the last school hour. Another study also revealed that classical guidance service had not fully and well used by school counselors because they did not consider classroom guidance service as important service and in its implementation, school counselors experienced difficulty in allocating time to perform classroom guidance service (Kristinawati, 2017).

The results of an evaluation of guidance and counseling programs at Public Madrasah Aliyah 2 High Schools Makassar found that service in classroom guidance was only conducted once, at the beginning of the academic year as orientation service, but then classroom guidance service was eliminated because of the limitation of time (Nirwana, 2016). This is supported by the study conducted by Demirel \& Yazgünoğlu (2013) which revealed that the most significant problem faced when implementing guidance service activity with the class setting was limited time. Meanwhile, in the education foundation from Universitas Lampung, Senior High School in Bandar Lampung, more often, school counselors performed group service and individual service. The counselor provides information and consulting services when students need and come to the counseling room (Defriyanto \& Rahayu, 2015).

The rapid growth of technology nowadays has affected all aspects of life including the educational aspect, particularly the guidance and counseling field at schools. The use of technology in guidance and counseling service has been implemented. This is proven by previous researchers stating that the development of technology nowadays has made many school counselors use it as part of their daily job (Stifel et al., 2013). However, school counselors have not made the most of technology because most of them still have not used the technology effectively. Nuranisa \& Wiyono (2018) stated that classroom guidance service could be performed, but it did not run effectively because of the lack of motivation from the student side to participate in the activity. Students also considered that classroom guidance was less interesting particularly in the way it was delivered because it was merely delivered through lecturing.

In this more complex era, the use of technology has become a crucial thing. Classroom guidance also cannot escape this growing trend of technology use. Nowadays, classroom guidance requires innovation. Lecturing method, the use of an LCD or PowerPoint will not be enough anymore to deliver classroom guidance. Classroom guidance must also follow the trend and the development of this era of digital technology. Previous research stated that more media is used in classical guidance, the more the students with guidance service (Artiani, 2018). The use of technology has become very crucial nowadays to give better service to students. Considering that there are still many obstacles occurring in the practice of guidance and counseling, this article offers classroom guidance with flip classroom format as an effort to overcome the obstacles in time allocation of classroom guidance practice.

The change in technology occurring nowadays has a big impact on the student's study culture. Today, there is this trend of online-based learning through the internet. There are lots of learning sources that are well and interestingly packaged so that students are motivated to learn. In this case, the school counselor needs to adjust to the changing conditions of technology. School counselors can learn how to give classical guidance more interestingly. To meet educational demand in the $21^{\text {st }}$ century, it is important to apply an innovative approach in education (Ozdamli \& Asiksoy, 2016). School counselors should make themselves 
compatible with the characters of their students who are Alpha and $\mathrm{Z}$ generation born in the digital era. This generation is characterized by an interest in information technology, they are more interested in environmental conditions that accommodate technological sophistication. It is expected that counselors can innovate in the provision of guidance and counseling services by using the advancement of technology. Carlson, Portman, \& Bartlett (2006) stated that a challenge for school counselors is to integrate technology into the service activity to fulfill the demand of a comprehension counseling program and to meet the need of student's development.

There are many forms of technology that can be used by school counselors as an effort to make classical guidance better. One of the ways is by implementing hybrid learning, which is a two-directions learning, an online class and face-to-face class (Kaur, 2013), or also what is commonly called blended learning (Husamah, 2015a, 2015b). Blended learning itself also has types of learning format, and one of them is a flipped classroom format. Strayer (2012) said that the flipped classroom is a part of blended learning, which is a learning process that uses technology in combining online and face-to-face classes.

Flip teaching has recently gained popularity (Bergmann \& Sams, 2 012). The results of some researches have revealed the effectiveness of the flipped classroom. Nouri (2016) reported that $75 \%$ of students who had low academic performance had a positive attitude towards the flipped classroom method with video as media. The flipped classroom can improve student's performance in preparing an examination (Mason, Shuman, \& Cook, 2013), improving verbal-linguistic intelligence (Hasanudin \& Fitrianingsih, 2019) and optimizing self-learning at home (Herreid \& Schiller, 2013). A research conducted by Mulawarman et al. (2019) reported that flip classroom guidance using animation video can improve self-esteem and optimism in prospective counselors.

Many previous kinds of research on flip classrooms are still about the learning of school subjects while in character learning is still rare. However, there is also research stating that the concept of blended treatment is still considered new. This concept refers to treatment which not only occurs during the face-to-face session but also involves intervention through digital components (Wentzel, van der Vaart, Bohlmeijer, \& van Gemert-Pijnen, 2016). The flipped classroom can contribute positively to education, and with the support of the blended treatment concept, it is time for school counselors to implement flipped classrooms in classroom guidance. Flipped classroom in guidance and counseling services is important to be implemented with the hope of increasing student interest and motivation towards the content provided through guidance and counseling services.

Flipped classrooms actually can be implemented in classroom guidance. In its implementation, school counselors can upload the course content/material of classical service during online service, and ask students to discuss the material again in offline session. The service material/content is the material that is needed by students covering the social aspect, learning, and career aspect. In its practice, school counselors may use a learning application that supports the implementation of the flipped classroom. It is also that implementing flipped classrooms in classroom guidance can contribute positively to students helping them improving social life, learning, and also career and in shaping in their characters. In compiling this article, the thing done is to examine some literature related to classroom guidance and also flipped classroom, where the literature is divided into various forms, both from books, previous research results, and e-books.

\section{METHODS}

The method used in this research is the library method. library research is research conducted with the method of examining research, books, literature, and reports that have a relationship with the topic of research conducted (Nazir, 2003). 


\begin{tabular}{|c|c|c|c|}
\hline No & Title of the Paper & Author/Year & Target \\
\hline 1. & $\begin{array}{l}\text { The flipped classroom: A } \\
\text { learning model to increase } \\
\text { student engagement, not } \\
\text { academic achievement }\end{array}$ & (Smallhorn, 2017) & $\begin{array}{l}\text { College of Science } \\
\text { and } \\
\text { Engineering }\end{array}$ \\
\hline 2. & $\begin{array}{l}\text { Enhancing Self-Esteem And } \\
\text { Optimism Based On Flipped } \\
\text { Classroom Guidance On } \\
\text { Undergraduate Counseling } \\
\text { Student In Indonesia }\end{array}$ & $\begin{array}{l}\text { (Mulawarman, } \\
\text { Nugroho, Susilawati, } \\
\text { Afriwilda, \& } \\
\text { Kunwijaya, 2019) }\end{array}$ & $\begin{array}{l}\text { Guidance and } \\
\text { Counseling students } \\
\text { of Semarang State } \\
\text { University }\end{array}$ \\
\hline 3. & $\begin{array}{l}\text { Developing information literacy } \\
\text { and critical thinking skills } \\
\text { through domain knowledge } \\
\text { learning in digital classrooms: An } \\
\text { experience of practicing flipped } \\
\text { classroom strategy }\end{array}$ & (Kong, 2014) & $\begin{array}{l}\text { A secondary school } \\
\text { in Hong Kong }\end{array}$ \\
\hline 4. & $\begin{array}{l}\text { An EFL Flipped Classroom } \\
\text { Teaching Model: Effects on } \\
\text { English Language Higher-order } \\
\text { Thinking Skills, Student } \\
\text { Engagement, and Satisfaction }\end{array}$ & (Alsowat, 2016) & $\begin{array}{l}\text { Students of Taif } \\
\text { University in Saudi } \\
\text { Arabia. }\end{array}$ \\
\hline 5. & $\begin{array}{l}\text { The flipped classroom: for active, } \\
\text { effective and increased learning - } \\
\text { especially for low achievers }\end{array}$ & (Nouri, 2016) & $\begin{array}{l}\text { Undergraduate } \\
\text { students at } \\
\text { Stockholm } \\
\text { University in } \\
\text { Sweden }\end{array}$ \\
\hline
\end{tabular}

Table 1. Lists articles with flipped classroom strategies

\section{Research procedure}

This research method library is used to find out the effectiveness of the flipped classroom strategy for improving character in the educational sphere. Kuhlthau, Heinström, \& Todd (2008) mentions several steps in conducting a literature study as follows: topic selection, information exploration, determining research focus, collecting data sources, preparing data presentation, preparing reports.

\section{Data source}

In research the data needed is from previous research related to the effectiveness of the flipped classroom strategy in developing the character and competence of students in the educational sphere, flip implementation procedure in a character role. The scope and target of application in secondary and tertiary education. Suggestions and recommendations in the scope of education. The criteria for the article adopted in this paper are as follows; 1) Data obtained from online, which is accessed as a source of data collection https://scholar.google.co.id; 2) 2010-2020 publication year; 3) The method used is using the flipped classroom strategy.

\section{Data Collection Techniques and Instruments}

Data collection can be started from researchers studying and searching for related literature on the topic (Creswell, 2014). In this case the use of the flipped classroom. This is done to provide information to the reader regarding the results of other studies that have been 
conducted related to the flipped classroom. In this study, the reading material used as a source of reference and research material is presented in the table 1 .

\section{RESULTS AND DISCUSSION}

The results of studies on the success of flipped classrooms in the sphere of education are discussed as follows:

Paper 1: The results show an increase in student participation and a positive attitude towards the method of flipping class. However, there is no increase in student learning outcomes that can be improved. Procedure flipped classroom: The flipped classroom strategy in the study used the Moodle Flinders Learning Online (FLO) application. Learning material in the form of videos is given a few days before the learning process takes place. Students are given the assignment to discuss in a face-to-face meeting. Implement a flipped classroom strategy for 6 weeks. Every week evaluation is given to determine student involvement, student interest, and academic value. Recommendation: The advice given in this research is that it is necessary to redesign the curriculum needed to change the traditional classroom model to the flipped classroom model. This requires a considerable amount of commitment and time from the teaching team. This allows educators the opportunity to reflect on teaching practices, redesign curriculum based on good practice and build stronger relationships with students.

Paper 2: This study shows that the flip class guidance method with animated video media has proven effective in increasing the self-esteem and optimism of prospective counselor students. Procedure flipped classroom: The flipped classroom guidance strategy is implemented using an Android-based application, Edmodo. The material in the form of animated video is given two days before face to face in class. At the class meeting, the discussion was conducted with a duration of 45 minutes. The instrument used is the selfesteem scale. Recommendation: From this study, it is recommended that research on more diverse studies be recommended for future research. And the use of other media and the more complete material that can be combined with the flip class method is also given to get more optimal results.

Paper 3: In this research, it is known that the use of flipped classroom can improve students' literation of information and critical thinking skills. Procedure flipped classroom: The flipped classroom structure is given for 13 weeks for 2 years, the learning process lasts for 40 minutes, forms a group of 3 members, each group uses a tablet PC to do the assignments and analyzes the information provided to practice critical thinking, then the evaluation stage through discussion. Recommendation: From the results of the research conducted, the researcher can provide one possible direction for future research, namely to strengthen the role of inverted classrooms in encouraging students' interactive learning for the development of skills outside of class time. The meaningful use of digital communication tools, such as social learning platforms, will help in this aspect. Because the approach to developing information literacy competencies and critical thinking skills through the learning of the domain of knowledge in digital classrooms is relatively new for school education, therefore further support and research are needed for teacher development that enables teachers to improve competency in this aspect.

Paper 4: The findings of this study reveal a statistically significant difference between the two groups in HOTS that supports the experimental group. Also, there are significant differences between pre and post-administration involvement scale in supporting postal administration. Besides, student satisfaction with (EFL-FCTM) is high. Finally, there is a highly significant relationship between HOTS and student involvement, HOTS and satisfaction and between student involvement and satisfaction. Procedure Flipped classroom: In this study flipped classroom was applied based on the theory of taxonomy blooms, in 
which at-home students apply low-level thinking skills (LOTS) through applying, remembering, and understanding the content provided in the video form. Students are also given the task to search for references outside the material given by the teacher. Implementation during face-to-face meetings students apply high-level thinking skills (HOTS), namely with indicators; creating, evaluating, and analyzing. Recommendations: Suggestions from this research that it is important to conduct more studies in experimenting with inverted classroom teaching models for language skills; listening, speaking, reading, writing, vocabulary and grammar because conventional models may not be suitable for some skills. In further research, it is necessary to examine various aspects that can contribute to the success of reverse teaching in language learning, such as student abilities, learning styles, cognitive and metacognitive strategies.

Paper 5: The results showed that the majority of students had positive attitudes toward flipped classroom, video and Moodle use and that positive attitudes toward reverse class were highly correlated with a perceived increase in motivation, involvement, increased learning, and effective learning. Procedure Flipped classroom: The flipped classroom strategy is segmented into three parts. The first is that students look for special literature and are presented with 3 videos each with a duration of 60 minutes related to the research strategy to get an understanding related to the theory given. Learning management system (Moodle). The second stage is grouping students to complete the project, the project results in the form of reports presented with a duration of 35 minutes for each group. In the third stage students are given 7 videos with a duration of 30 minutes each, then discussed. The final survey results by distributing four measurement scales namely (General information, Flipped Classroom Scale, Video Scale, LMS Scale). Recommendations: Future research recommendations that are about the effects of inverted classes need to overcome the limitations of this study. The limitations of this study are the absence of a control group that limits the external validity of the results. And in particular, explore the extent to which students' actual performance is or is not affected by the inverse class approach moving beyond student perceptions alone.

\section{Classroom guidance}

Classroom guidance is a planned instruction, which is given to all students in the form of class or a big group of students. Fandini (2018) stated that classroom guidance is a service that is given to students by school counselors to all students in a class. Moreover, ZiomekDaigle (2016) added that classroom guidance is a guidance that is delivered through the class program and integrates a wider topic related to daily experiences such as living at home, becoming a good citizen, taking care of themselves, and socializing with other people. From some of those statements, it can be said that classroom guidance is a guidance that is performed in class format to develop students potential. In conjunction with this statement, another research conducted by Mukhtar, Yusuf, \& Budiamin (2016) reported that classroom guidance service is effective to improve student's self-control.

Classroom guidance is guidance given in group format in the classroom setting. The number of students participating in classroom guidance service is the whole members of the class. According to Winkel \& Hastuti (2012), classroom guidance is an instrument that can be used by school counselors to support students' development. The function of classroom guidance is as prevention function, maintenance function, and understanding function, which means that through classical guidance, students can process information and apply it as an effort to develop themselves. Classroom guidance is given as an effort to develop students' personal, social, learning, and career aspect. Nurihsan (2016) stated that the purpose of classroom guidance is; 1) students can make a study plan, plan career development, and plan their future life; 2) students can develop their ability as well as their potential optimally as an effort to achieve development task; 3) students can adapt themselves in either school, family, 
society, or work environment; 4) students can face and resolve any problem they face in learning, social, personal, and career life.

One of the service models that can be applied by school counselors in this digital era in terms of classroom guidance service is integrating the Learning Management System (LMS), which is a flipped classroom. Bergman \& Sams (2014) identified technology as "obstacles" to implement the flipped classroom. Flipped classroom technology becomes an integral part, and its use is related to the context where the class is offered. However, what is more, important and needs to be taken into account is how the design of a flipped classroom can be applied in classroom guidance service, which what in this article is called flipped classroom guidance.

\section{Step 1}

1.Formulating the goal of classroom guidance service

- Suitable to affective, cognitive, and psychomotor aspects.

-Process and result oriented.

-Fulfilling criteria A (audience), B (behavior), C (condition), D (degree).

-The use of online media to perform pre class learning activities independently.

-Determining learning process that will be performed in the class together with the school counselors and peers.

\section{Step 2}

\section{Delivering Content}

- The content given related to guidance and counseling domain which is study guidance, personal guidance, social guidance, and career guidance, as well as students development aspects.

-Using and integrating many sources and learning techniques

- Facilitating students to absorb information by providing students with less than 15 minutes learning video

Step 3 Aspects Supporting Classical Guidance Service, Structure and Interaction

-The practice of the service is adjusted to constructive theory.

-Developing complexity by students encouragement.

-Learning activities are based on the content that has been learnt online.

-Building interaction with peers and school counselors for strengthening.

Figure 1. Stages of the flipped classroom guidance strategy

\section{Flipped Classroom}

The term flipped classroom was created in 2012 by two chemistry senior high school teachers from Colorado, Bergmann, and Sams (2012) who started to teach using this model in 2007. The flipped classroom model is the opposite of the traditional service model, the model that runs the service for the students in a classroom. In the flipped classroom, students are the ones who are more active and collaborative in the process of the service. This can be done through application and evaluation activities in class, an activity that develops critical thinking and creativity (Wallace, Walker, Braseby, \& Sweet, 2014).

Most publications describe the flipped classroom as a type of blended learning (Abeysekera \& Dawson, 2015). The flipped classroom is a service model consisting of two activities, first activities in the form of the group held actively in the class and second is a service activity that is given directly to students with the help of technology advancement outside class. In the flipped classroom model, the material can be given in the form of reading and instructional video, and in-class learning there is usually homework (Garrison \& Kanuka, 2004; Tucker, 2012). Therefore, the flipped classroom model gives some time for educators to 
deliver the material to students (outside the classroom) and involves students in activity inside the class (Bergmann \& Sams, 2012).

There are some advantages to using the flipped classroom model. One of the advantages is that this model can identify and meet the students' needs individually (Educause, 2012). With the flipped classroom, students can also learn and review the material in their way (Nilson, 2013). If the students cannot understand the material, they can relearn the material until they better understand it. Besides, the flipped classroom is an improvement of the use of technology that allows school counselors to better deliver the material in a more modern way (Bergmann \& Sams, 2012) and employs various learning styles through some different learning methods (Mason et al., 2013). The use of a flipped classroom can fulfill the need of students individually and can develop the student's skills and improve student's engagement with teachers in the class (Milman, 2014).

To implement the use of the flipped classroom, there are some challenges needed to be resolved. For students, they must learn the material before the class starts and discuss the material that has been learned during the class face-to-face. However, if the students do not study the material before the class, the in-class activities will not be effective. Students will not participate in the actively in-class discussion. In addition, students will also be limited to ask questions and accept answers directly during outside classroom activities (Bergmann \& Sams, 2012). Meanwhile, the challenge for educators is the initial preparation to implement the flipped classroom model covering things necessary to be prepared for student's activities during inside and outside class (Educause, 2012). Furthermore, the author will discuss the implementation of classroom guidance using the flipped classroom method. In this article, the flipped classroom will be called flipped classroom guidance.

\section{Flipped Classroom Guidance Method}

Professional school counselors are required to have broad knowledge and to understand the changes of the era, such as the rapidly growing digital era. By embracing the fast-growing of the digital era, school counselors can be motivated to improve their performance through the digital path in giving guidance service for the students. The development of this digital pattern is necessary. This development of the digital era is contributed by the millennial generation as the dominant users of the internet. Here in Indonesia, millennial generation internet users reach 143 million internet users in Indonesia are the millennial generation, and $49.5 \%$ of those users are aged 19-34 years old. Digital technology can be used by making innovation resulting in the more methods that can be used by school counselors to deliver their guidance service. By using digital media and various innovative guidance service methods, it is expected that students will better absorb and understand the content of the service because it is interesting (Firman, 2019).

Guidance and counseling service is an integral part of the education service. This service can help the student to develop optimally. The strategies that school counselors may do for students who need service and guidance are 1) encouraging and facilitating students to express creative and innovative ideas, 2) facilitating students to modify ideas to develop innovation, 3) giving feedback, and 4) using the existing information and experience to formulate an approach/strategy and guidance and counseling service that is needed (Firman, 2019).

Flipped classroom guidance gives time efficiency because the content is given online and learned independently by students at their home before the face-to-face session in the class occurs. Flipped classroom guidance also stimulates students to be active during the process of classroom guidance service. School counselors may innovate the way they perform classroom guidance services by using a flipped classroom. By doing so, school counselors can take advantage of technology and overcome time limitations by using a smartphone. Flipped 
classroom guidance design is similar to the traditional classical service model. The only difference is that in the flipped classroom guidance model there is an additional instructional phase to explain the design process. According to Chen Hsieh, Wu, \& Marek (2017), there are three components in flipped classroom design that can be adapted in classroom guidance service.

As mentioned previously, the flipped classroom is a method of reversing class, meaning that what is usually done in the classroom is done outside the classroom in the form of discussion. In performing flipped classroom guidance, the activities are based on the Learning Management System (LMS). This system is the implementation of the software program for online activities, the e-learning program, and the content of the training. One example of an elearning application is the Edmodo application. This application can be used to help school counselors run flipped classroom guidance (Ziomek-Daigle, 2016). Edmodo application is a learning application using electronic media that can be used to share video, task, students' discussion activities, and it can also be used to contact the students.

Flipped classroom guidance has a basic idea that service must be performed well through various media both inside and outside the classroom. Flipped classroom guidance has two learning environments: outside and inside the classroom. Both must be integrated well so that this model can be effective. Based on the design components of flipped classroom guidance aforementioned, the steps that are taken by school counselors to implement flipped classroom guidance are planning, implementation, and evaluation.

During the planning stage, school counselors need to arrange and prepare the plan for the activities that will be performed during flipped classroom guidance. The first step to be taken is determining the topic that will be delivered to the students based on the result of need assessment by considering Students Independent Competence Standard (Nasional, 2007). Next, the counselors arrange Service Program Plan containing a predetermined topic. After the making of RPL, the next step is to set in detail the activities that will be performed during the pre-class and during the class.

\begin{tabular}{ll}
\hline \multicolumn{1}{c}{ Pre Class Activity } & \multicolumn{1}{c}{ Activity in the Class } \\
\hline $\begin{array}{l}\text { 1. Counselors make media that will be } \\
\text { delivered to students based on the given } \\
\text { topic (in the form of video, paper, etc } \\
\text { that can be downloaded by the student) }\end{array}$ & $\begin{array}{l}\text { 1. Counselors instruct students to make } \\
\text { groups in the class. The purpose of } \\
\text { making groups is to discuss the course } \\
\text { content that has been learned } \\
\text { independently by students. }\end{array}$ \\
$\begin{array}{l}\text { 2. Counselors give the course } \\
\text { content/material to the students before } \\
\text { the face-to-face activity (at least 3 days } \\
\text { before the class activity) }\end{array}$ & $\begin{array}{l}\text { perform discussion activities in the class. } \\
\text { 3. Counselors instruct students to learn the } \\
\text { course content given so that they can } \\
\text { discuss it in the face-to-face activity }\end{array}$ \\
\hline
\end{tabular}
Table 2. Pre-class and pre-class activities

In the implementation stage, flipped classroom guidance is adjusted to the plan that has been made. In this case, counselors give the course content before the class and during the activity in the class. Some methods can be used to facilitate flipped classroom guidance. One of the methods is Project-Based Learning (PBL). In this activity, students perform exploration, assessment, and information synthesis to gain knowledge, skill, and attitude based on the content given. Another method is group discussion. In a group discussion, students can work together with their peers to share experience and knowledge so that they 
can create meaning and reach the goal of the guidance that cannot be reached if the guidance is performed individually. Counselors can also give some tasks to this discussion group. The tasks given facilitate the participants of the discussion to interact with each other such as asking the question, responding to each other statement or question, and evaluating their answer.

In the evaluation and follow-up stage, all that has been planned and performed need to be evaluated to make sure that flipped classroom guidance has reached the goal and to fix any lack that occurs during the process. Indicator of success of flipped classroom guidance can be seen from outputs (attendance, online activity, the result of the assessment) and outcomes (change of attitude, developing skills, wider knowledge). Students and school counselors are also evaluated. The evaluation covers comprehension, mastery, advantages, and impact felt by students related to the course that has been learned. One of the challenges for school counselors is that not all courses or materials regarding counseling are available in the form of video that can be downloaded online. School counselors sometimes need to make a video relevant to the topic that will be delivered. It takes a quite long time to learn the technology and to make a video to be used as a pre-class activity.

The application of a method in the practice of guidance and counseling service has its advantages and disadvantages. The one advantage of flipped classroom guidance according to Nilson (2013) is that students may learn the content given in a manner that suits them best. In addition, there is another study stated that there is a chance for students to re-watch and relearn the video given if they have not understood it the first time they watch. Moreover, through the flipped classroom, students have a chance to contribute more and to work together with their peers during the face-to-face process (Moran \& Milsom, 2015). With flipped classroom guidance, the counselors can make the most of face-to-face class time for discussion and evaluation.

On the other side, flipped classroom guidance also has a limitation. Flipped classroom guidance demands students to be able to learn the content in pre-class activities independently before the process of face-to-face activity occurs (Nilson, 2013). Another limitation is that students are demanded to seriously learn the content given before the class because in face-toface class activity, the agenda applied is reviewing the material deeply, thus students need to have a better understanding of the material given (Moran \& Milsom, 2015). In addition, limitation in technology faced by students and limited internet access across Indonesia has inhibited students' activity to learn course content. Moreover, counselors are also challenged to deliver the content in the form of video attractively for the students to be interested.

The implication of flipped classroom guidance given to school counselors is to allow school counselors to be able to make innovation in the method of performing guidance and counseling service at schools. Thus, the effort to create innovation in guidance and counseling method particularly in classroom guidance can be achieved and therefore, this will support the need of students because classroom guidance is a basic service. Basic service is a type of service that is performed actively by a school counselor by applying a more up to date method. Through flipped classroom guidance, school counselors can integrate technology to meet the demand for the advancement of the digital era that becomes more and more complex. The limitations of this article are there still few articles that discuss the effectiveness of flipped classroom strategy to develop competencies or character of students specifically in the field of counseling.

\section{CONCLUSIONS}

Flipped classroom guidance is an effort that can be made by school counselors to make innovation in performing classroom guidance service, considering that nowadays technology advancement has given a great impact in the field of education world as well as on students' 
studying culture. Based on the results of the assessment of five articles, it can be concluded that the reverse class is used to improve students' abilities such as critical thinking skills, and other psychological attributes such as self-esteem, and optimism.

The brief steps/procedures of flipped classroom guidance determine the topic needed to be addressed, arranging a service program plan, setting up the activities which will be done in pre-class and in class, performing the activities and evaluation, and following up. In general, components that must be present in flipped classroom guidance design are formulating the purpose of classical guidance service, presenting the material, and other supporting aspects of classical guidance service, structure, and interaction. The space discussing the use of flipping classes in five more articles at the higher education or university level is issued at school.

The effectiveness of flipped classroom guidance in guidance and counseling service still needs to be proven scientifically. Therefore, future researchers are expected to be able to research to test the effectiveness of flipped classroom guidance and relate it with variables covering personal, social, academic, and career development. Besides that, flipped classroom research in schools needs to be reproduced.

\section{ACKNOWLEDGMENTS} study.

Authors would like to sincere their gratitude to everyone who was involved in this

\section{AUTHOR CONTRIBUTION STATEMENTS}

All authors have agreed with the final version of this article.

\section{REFERENCES}

Abeysekera, L., \& Dawson, P. (2015). Motivation and cognitive load in the flipped classroom: definition, rationale and a call for research. Higher Education Research \& Development, 34(1), 1-14. https://doi.org/10.1080/07294360.2014.934336

Alsowat, H. (2016). An EFL flipped classroom teaching model: Effects on English language higher-order thinking skills, student engagement, and satisfaction. Journal of Education and Practice, 7(9), 108-121. Retrieved from Google Scholar

Artiani, A. O. (2018). Hubungan Antara Penggunaan Teknologi Media Bimbingan Klasikal. [Thesis]. Universitas Islam Negeri Sunan Kalijaga. Retrieved from Google Scholar

ASCA, A. (2003). The ASCA national model: A framework for school counseling programs. Professional School Counseling, 165-168. Retrieved from Google Scholar

Bergmann, J., \& Sams, A. (2014). Flipping for mastery. Educational Leadership, 71(4), 2429. Retrieved from Google Scholar

Carlson, L. A., Portman, T. A. A., \& Bartlett, J. R. (2006). Professional school counselors' approaches to technology. Professional School Counseling, 252-256. https://www.jstor.org/stable/42732679

Chen Hsieh, J. S., Wu, W. C. V., \& Marek, M. W. (2017). Using the flipped classroom to enhance EFL learning. Computer Assisted Language Learning, 30(1-2), 1-21. https://doi.org/10.1080/09588221.2015.1111910

Creswell, J. W. (2014). Research Design Quantitative, Qualitative, and Mixed Method Approaches ( $4^{\text {th }}$ Edition). SAGE Publications. Retrieved from Google Scholar

Defriyanto, D., \& Rahayu, D. J. (2015). Evaluasi Program Bimbingan dan Konseling Dalam Mengatasi Perilaku Membolos Peserta Didik di Sekolah Menengah Atas (SMA) Yp Unila Bandar Lampung. KONSELI: Jurnal Bimbingan Dan Konseling (E-Journal), 2(2), 69-76. http://www.ejournal.radenintan.ac.id/index.php/konseli/article/view/1461

Demirel, M., \& Yazgünoğlu, S. (2013). The evaluation of classroom guidance activities in 
primary schools. Procedia-Social and Behavioral Sciences, 93, 1598-1602. https://doi.org/10.1016/j.sbspro.2013.10.088

Depdiknas, P. K. B. (2007). Naskah akademik kajian kebijakan kurikulum Pendidikan Kewarganegaraan. Jakarta: Pusat Kurikulum Balitbang Depdiknas. Retrieved from Google Scholar

Educause, E. (2012). 7 things you should know about flipped classrooms. Retrieved from Google Scholar

Fandini, H. S. (2018). Pengembangan Adobe Flash sebagai Media Layanan Informasi Peminatan Studi Lanjut SMA dan Sederajat Untuk Siswa Kelas IX SMPN 5 Sidoarjo. Jurnal BK Unesa, 8(1). https://jurnalmahasiswa.unesa.ac.id/index.php/jurnalbk-unesa/article/view/22735

Firman, F. (2019). Strategi Dan Pendekatan Pelaksanaan Bimbingan Konseling Di Sekolah Untuk Menghadapi Revolusi Industri 4.0. Retrieved from Google Scholar

Garrison, D. R., \& Kanuka, H. (2004). Blended learning: Uncovering its transformative potential in higher education. The internet and higher education, 7(2), 95-105. https://doi.org/10.1016/j.iheduc.2004.02.001

Hasanudin, C., \& Fitrianigsih, A. (2019). Analisis Gaya Belajar Mahasiswa Pada Pembelajaran Flipped Classroom. Jurnal Pendidikan Edutama, 6(1), 31. https://doi.org/10.30734/jpe.v6i1.364

Herreid, C. F., \& Schiller, N. A. (2013). Case studies and the flipped classroom. Journal of College Science Teaching, 42(5), 62-66. https://www.jstor.org/stable/43631584

Husamah. H. (2015a). Thinking skills for environmental sustainability perspective of new students of biology education department through blended project based learning model. Jurnal Pendidikan IPA Indonesia, 4(2), 110-119. https://doi.org/10.15294/jpii.v4i2.3878

Husamah, H. (2015b). Blended Project Based Learning: Metacognitive Awareness of Biology Education New Students. Journal of Education and Learning (EduLearn), 9(4), 274. https://doi.org/10.11591/edulearn.v9i4.2121

Kaur, M. (2013). Blended learning-its challenges and future. Procedia-Social and Behavioral Sciences, 93, 612-617. https://doi.org/10.1016/j.sbspro.2013.09.248

Kong, S. C. (2014). Developing information literacy and critical thinking skills through domain knowledge learning in digital classrooms: An experience of practicing flipped classroom strategy. Computers and Education, 78, 160-173. https://doi.org/10.1016/j.compedu.2014.05.009

Kristinawati, T. D. (2017). Perbedaan persepsi siswa terhadap layanan bimbingan klasikal terjadwal dan tidak terjadwal (studi komparatif pada siswa kelas IX SMP Kanisius Sleman dan SMP Taman Dewasa Jetis Yogyakarta tahun ajaran 2017/2018) [Thesis, Sanata Dharma University]. https://repository.usd.ac.id/13148

Kuhlthau, C. C., Heinström, J., \& Todd, R. J. (2008). The 'information search process' revisited: Is the model still useful. Information research, 13(4), 13-4. Retrieved from Google Scholar

Mason, G. S., Shuman, T. R., \& Cook, K. E. (2013). Comparing the effectiveness of an inverted classroom to a traditional classroom in an upper-division engineering course. IEEE transactions on education, 56(4), 430-435. https://doi.org/10.1109/TE.2013.2249066

Milman, N. B. (2014). The Flipped Classroom Strategy. Distance Learning, 11(4), 9-11. https://doi.org/10.1097/NNE.0000000000000096

Moran, K., \& Milsom, A. (2015). The flipped classroom in counselor education. Counselor Education and Supervision, 54(1), 32-43. https://doi.org/10.1002/j.15566978.2015.00068.x 
Mukhtar, M., Yusuf, S., \& Budiamin, A. (2016). Program Layanan Bimbingan Klasikal untuk Meningkatkan Self-Control Siswa. PSIKOPEDAGOGIA Jurnal Bimbingan dan Konseling, 5(1), 1-16. Retrieved from Google Scholar

Mulawarman, M., Nugroho, I. S., Susilawati, S., Afriwilda, M. T., \& Kunwijaya, I. (2019). Enhancing Self-Esteem and Optimism Based on Flipped Classroom Guidance On Undergraduate Counseling Student In Indonesia. European Journal of Education Studies. 6(5). https://doi.org/10.5281/zenodo.3382157

Nasional, D. P. (2007). Rambu-Rambu Penyelenggaraan Bimbingan dan Konseling dalam Jalur Pendidikan Formal. Jakarta: Direktorat JenderalPeningkatan Mutu Pendidikan dan Tenaga Kependidikan Departemen Pendidikan Nasional. Retrieved from Google Scholar

Nazir, M. (2003). Metodologi Penelitian Bisnis. Jakarta: Ghalia Indonesia. Retrieved from Google Scholar

Nilson, L. (2013). Flipping your classroom: What does it mean? PowerPoint presented at the Office of Teaching Effectiveness and Innovation. Clemson University. Retrieved from Google Scholar

Nirwana, N. (2018). Evaluasi program kerja Bimbingan Konseling di MAN 2 Model Makassar [Master's Theses and Graduate Research, Universitas Negeri Makassar]. http://eprints.unm.ac.id/10174

Nouri, J. (2016). The flipped classroom: for active, effective and increased learning especially for low achievers. International Journal of Educational Technology in Higher Education, 13(1). https://doi.org/10.1186/s41239-016-0032-z

Nuranisa, N., \& Wiyono, B. (2018). Studi Implementasi Strrategi Bimbingan Klasikal Di $\begin{array}{llllll}\text { SMP Negeri } 13 \text { Surabaya. Jurnal } & \text { BK }\end{array}$ https://jurnalmahasiswa.unesa.ac.id/index.php/jurnal-bk-unesa/article/view/24776

Nurihsan, A. J. (2016). Bimbingan dan Konseling: dalam berbagai latar kehidupan. Bandung: Refika Aditama. Retrieved from Google Scholar

Ozdamli, F., \& Asiksoy, G. (2016). Flipped Classroom Approach. World Journal on Educational Technology: Current Issues, 8(2), 98-105. https://doi.org/10.18844/wjet.v8i2.640

Rismawati, R. (2015). Pelaksanaan Layanan Klasikal Bimbingan Dan Konseling Di SMP Negeri 3 Kandangan. Jurnal Mahasiswa BK An-Nur: Berbeda, Bermakna, Mulia, 1(2), 64-73. http://dx.doi.org/10.31602/jmbkan.v1i2.360

Strayer, J. F. (2012). How learning in an inverted classroom influences cooperation, innovation and task orientation. Learning environments research, 15(2), 171-193. https://doi.org/10.1007/s10984-012-9108-4

Stifel, S. W. F., Brown, J. A., Jimerson, S. R., \& Dowdy, E. (2013). Integrating Email Communication with Counseling at School. School Mental Health, 5(2), 110-118. https://doi.org/10.1007/s12310-012-9086-9

Tucker, C. R. (2012). Blended learning in grades 4-12: Leveraging the power of technology to create student-centered classrooms. Thousand Oaks, CA: Corwin Press. Retrieved from Google Scholar

Wallace, M. L., Walker, J. D., Braseby, A. M., \& Sweet, M. S. (2014). " Now, What Happens During Class?" Using Team-Based Learning to Optimize the Role of Expertise Within the Flipped Classroom. Journal on Excellence in College Teaching, 25(3), 253-273. Retrieved from Google Scholar

Wentzel, J., van der Vaart, R., Bohlmeijer, E. T., \& van Gemert-Pijnen, J. E. (2016). Mixing online and face-to-face therapy: how to benefit from blended care in mental health care. JMIR mental health, 3(1), e9. http://doi.org/10.2196/mental.4534 
Winkel, W. S., \& Hastuti, M. S. (2006). Bimbingan dan Konseling di institutusi Pendidikan. Yogyakarta: Media Abadi. Retrieved from Google Scholar

Ziomek-Daigle, J. (Ed.). (2015). School counseling classroom guidance: Prevention, accountability, and outcomes. SAGE Publications. Retrieved from Google Scholar

\section{Copyright holder :}

(C) Mulawarman, M., Susilawati, S., Syifa, L., \& Rifani, E (2020)

First publication right :

(c) Islamic Guidance and Counseling Journal

This article is licensed under:

CC-BY-SA 